\title{
SASAT 1. \\ Hal: $115-128$ \\ PERSEPSI PEJABAT PENGGUNA ANGGARAN TERHADAP EFEKTIVITAS IMPLEMENTASI ANGGARAN BERBASIS KINERJA DITINJAU DARI ASPEK RASIONAL (Survei pada Pemerintah Kota Surakarta)
}

\author{
Djoko Suhardjanto \\ Universitas Sebelas Maret Surakarta \\ e-mail: suhardjanto04@yahoo.com \\ Bayu Tri Cahya \\ Universitas Sebelas Maret Surakarta \\ e-mail: @yahoo.com
}

\begin{abstract}
The objectives of this research is to examine the influence of rational aspects such as resources, information, goal orientation and the measuring performance upon the implementation of the effectiveness performance based budgeting. Tthis research uses purposive sampling to get data. There are 72 respondents who have responsibilities in the budgeting in district working unit in local government Surakarta. Results of multiple regression analysis show that resources variable (p-value 0.031) and performance measurement system (p-value 0.005) affect positively the effectiveness of the implementing performance based budgeting in local government. It means that an increase in resources and development in performance measurement will increase the effectiveness of budgeting.
\end{abstract}

Keywords:effectiveness, performance, budgeting, resources, information, measurement

\section{PENDAHULUAN}

Perkembangan reformasi sektor publik yang begitu dinamis saat ini tidak dapat dilepaskan dari tuntutan masyarakat yang melihat secara kritis buruknya kinerja pemerintah dalam mengelola sumber daya publik. Perubahan berbagai aspek yang dibawa oleh arus reformasi telah menimbulkan tuntutan yang beragam terhadap pengelolaan pemerintahan yang baik (Asmadewa, 2006).

Agenda-agenda reformasi terhadap tuntutan perubahan organisasional kemudian menciptakan sejumlah prinsip atau doktrin tata kelola pemerintahan seperti terangkum dalam konsep new public management (Hood, 1991), atau prinsip reinventing goverment (Osborne and Gaebler, 1993).
Hal ini seperti yang telah dilakukan di Amerika Serikat pada awal mula mengimplementasikan anggaran berbasis kinerja yaitu dengan dibentuknya Komisi Hoover pada tahun 1949 untuk mendukung konsep anggaran berbasis kinerja hingga diberlakukannya GPRA (Government Performance and Result Act) tahun 1993. GAO (General Accounting Office) tahun 1993 juga menjelaskan bahwa reformasi anggaran telah berusaha merubah penekanan anggaran dari pengendalian belanja line item kepada alokasi sumber daya berdasarkan tujuan program dan ukuran-ukuran hasil.

Anggaran berbasis kinerja di Indonesia telah diperkenalkan dalam Undang-Undang No. 17 tahun 2003 tentang Keuangan Negara yang menjelaskan bahwa 
rencana kerja dan anggaran disusun berdasarkan prestasi kerja yang akan dicapai atau berbasis kinerja. Penjelasan UndangUndang tersebut menguraikan bahwa anggaran berbasis prestasi kerja merupakan upaya untuk memperbaiki proses penganggaran di sektor publik. Selanjutanya disahkannya Permendagri No. 13 tahun 2006 dan Permendagri No. 59 tahun 2007 tentang pedoman pengelolaan keuangan daerah. Sesuai dengan Permendagri No. 13 tahun 2006 penganggaran yang baik akan memberikan dasar bagi pengukuran kinerja dan menghasilkan informasi kinerja yang valid dan akurat, sehingga dapat digunakan sebagai bahan penyusunan laporan kinerja untuk pengendalian.

Dilihat dari sudut pandang rasional, implementasi anggaran berbasis kinerja merupakan isu teknis. Sistem pengukuran kinerja yang dilandasi oleh konsep value for money, dan anggaran yang berorientasi hasil yang menekankan pemikiran logis dan rasional dalam mengelola suatu perubahan dalam suatu organisasi. Organisasi kemudian dapat dimodifikasi dengan mengaplikasikan perencanaan rasional secara ilmiah untuk mencapai efektivitas dan efisiensi keseluruhan organisasi (Julnez and Holzer, 2001).

Dengan mempertimbangkan perkembangan penelitian terdahulu yang masih beragam, maka evaluasi atas status implementasi anggaran berbasis kinerja yang telah dicapai pemerintah daerah saat ini penting untuk diteliti. Hal ini merupakan upaya untuk menjaga momentum perubahan ini agar selalu pada jalur yang tepat (Bastian, 2006). Karenanya, penelitian ini akan meneliti status perkembangan atau efektivitas implementasi anggaran berbasis kinerja pemerintah daerah terkait aspek rasional yang mempengaruhinya terkait perubahan dalam pendekatan anggaran di Indonesia.
Penelitian ini akan menanyakan persepsi para pejabat (penganggar) pada lembaga/instansi di lingkup pemerintah kota Surakarta tentang pengaruh aspek rasional (sumber daya, informasi, orientasi tujuan, dan pengukuran kinerja) terhadap efektivitas implementasi anggaran berbasis kinerja. Hal inilah yang merupakan perluasan penelitian yang membedakan dengan penelitianpenelitian sebelumnya.

\section{KAJIAN PUSTAKA}

\section{Anggaran Berbasis Kinerja}

Konsep performance budgeting (penganggaran kinerja) dalam sejarahnya diperkenalkan pertama kali di AS pada tahun 1949 oleh Komisi Hoover dimana reformasi anggaran telah berusaha merubah penekanan anggaran dari pengendalian belanja line item kepada alokasi sumber daya berdasarkan tujuan program dan hasil terukur (GAO, 1993).

Robinson and Brumby (2005) menjelaskan anggaran berbasis kinerja sebagai prosedur atau mekanisme yang dimaksudkan untuk memperkuat kaitan antara dana yang diberikan kepada entitas sektor publik dengan outcome dan/atau outcome mereka melalui penggunaan informasi kinerja formal dalam pengambilan keputusan alokasi sumber daya. Dimana anggaran tersebut berfokus pada aktivitas atau fungsi yang memproduksi hasil dan sumber daya yang digunakan serta memperkenalkan proses penganggaran yang berusaha untuk menghubungkan tujuan organisasi dengan sumber daya. Pada dasarnya tujuan utama anggaran berbasis kinerja ini adalah meningkatkan efisiensi dan efektivitas belanja publik dan GAO mendefinisikan anggran berbasis kinerja sebagai konsep yang mengkaitkan informasi kinerja dengan anggaran.

Menurut Mardiasmo (2002) anggaran dengan pendekatan kinerja disusun untuk mengatasi berbagai kelemahan yang ada di 
anggaran tradisional, khususnya kelemahan yang disebabkan oleh tidak adanya tolak ukur yang dapat digunakan untuk mengukur kinerja dalam pencapaian tujuan dan sasaran pelayanan publik.

Bagi Negara Indonesia sendiri, implementasi anggaran berbasis kinerja atau dalam Permendagri No.13 tahun 2006 disebut dengan anggaran pendekatan prestasi kerja merupakan pendekatan yang relatif baru diterapkan dalam sistem penganggaran di Indonesia.

\section{Konsep Reformasi Anggaran Berbasis Kinerja}

Proses reformasi anggaran di

Amerika Serikat timbul karena upaya dari gerakan progresif yang mengembangkan analisis sistematik terhadap aktivitasaktivitas pemerintahan dan operasi pemerintahan.

Analisis di masa lalu menunjukkan bahwa anggaran berbasis kinerja berhubungan dengan masalah-masalah yang secara institusional dari reformasi anggaran (Shick, 1971 dalam Willoughby and Melkers, 2001). Sebagai contohnya, implementasinya meliputi masalah-masalah berikut. 1) Kepemimpinan dan komitmen terhadap organisasi. 2) Kontinuitas dalam fokus reformasi administrasi. 3) Sumber daya yang cukup dalam usaha mewujudkan reformasi (waktu, uang, personel). 4) Harapan yang berlebihan akan kesuksesan.

Kegagalan reformasi anggaran sering disebabkan karena pemahaman yang tidak cukup oleh pelaksana anggaran dan syaratsyarat reformasi yang harus dipenuhi dalam proses penganggaran.

Howard (1973) menegaskan bahwa beberapa reformasi khususnya inisiatif untuk mengembangkan penganggaran yang lebih rasional bukan merupakan sebuah metode alokasi sumber daya, tetapi sebuah usaha untuk mendukung pembuatan keputusan. Sesuai dengan hal tersebut, kesuksesan dari reformasi anggararan tergantung pada penerimaan individual terhadap reformasi sama baiknya dengan kemauan mereka untuk merubah bagaimana mereka berpikir dan bertindak.

\section{Efektivitas Implementasi Anggaran Ber- basis Kinerja Dan Aspek Rasional}

Efektivitas implementasi anggaran berbasis kinerja dilihat dari sudut pandang rasional merupakan isu teknis. Sistem pengukuran kinerja yang dilandasi oleh konsep value for money, dan anggaran yang berorientasi hasil menekankan pada suatu pemikiran logis/rasional dan teknis dalam mengelola suatu perubahan dalam suatu organisasi.

Asmadewa (2006) berpendapat bahwa tahap implementasi anggaran berbasis kinerja merupakan tahap penggunaan informasi kinerja dalam proses penganggaran untuk memberikan dampak yang sebenarnya pada efisiensi, efektivitas, dan pengambilan keputusan, dan akuntabilitas. Pencapaian efektivitas implementasi anggaran berbaisi kinerja dapat dilihat dari keterkaitan hasil program dengan target atau tujuan yang ditetapkan.

Dalam proses pengimplemetasian anggaran berbasis kinerja, sejumlah literatur dan penelitian mengindikasikan adanya sejumlah aspek yang berpengaruh bagi keberhasilan implementasi tersebut adalah aspek rasional (Julnes and Holzer, 2001). Aspek rasional adalah aspek yang mendasarkan pada pemikiran logis/penalaran sebagai pertimbangan tertinggi untuk menentukan hal seperti pendapat, perbuatan, penilaian, dan sebagainya (Darmansjah, 2002). Penelitian Wang (2000) menemukan indikasi adanya hubungan antara pengembangan kapasitas pengukuran kinerja (melibatkan sumber daya dana, staf, dan sistem informasi) dengan penggunaan pengukuran kinerja dalam penganggaran. 


\section{Penelitian Terdahulu}

Beberapa penelitian mengenai efektivitas implementasi anggaran berbasis kinerja diantaranya adalah penelitian Crain and O'Roack (2004) menemukan kehadiran anggaran berbasis kineja baru dapat menurunkan belanja total dari negara bagian setidaknya sebesar $1,3 \%$ dari pendapatan di negara bagian, dan $2 \%$ per kapita. Hasil temuan ini sejalan dengan hasil survei yang dilakukan oleh Willlougby and Melkers (2000) terhadap penganggar di 49 negara bagian, baik eksekutif maupun legislatif. Tanggapan para responden dalam survei tersebut belum mengindikasikan adanya kemajuan implementasi dalam mempengaruhi aprosiasi yang dapat dikaitkan langsung dengan outcome dalam implementasi anggaran berbasis kinerja, hanya mendapat sedikit respon yaitu sepertiga dari eksekutif dan $43 \%$ dari legislatif yang berpendapat setuju dan sangat setuju. Demikian juga atas pertanyaan efektivitas anggaran berbasis kinerja merubah tingkat aprosiasi, rata-rata tanggapan sampel hanya menunjukkan 1,54 dari skala likert 1 sampai 4.

Penelitian lain tentang anggaran berbasis kinerja yang mengindikasikan adanya kemajuan diantaranya dari survei yang sama dilakukan oleh Willougby dan Melkers (2001), menemukan bahwa secara keseluruhan implementasi anggaran berbasis kinerja telah memberikan dampak perbaikan pada efektivitas program lembaga dan pengambilan keputusan dalam pemerintah. Sementara Jordan and Hackbart (1999) dalam penelitiannya atas status anggaran berbasis kinerja dan pendanaan kinerja, menemukan bahwa ketika anggaran berbasis kinerja diimplementasikan, maka pencapaian standar kinerja akan mempengaruhi rekomendasi dalam anggaran gubernur (eksekutif) dan kinerja dapat mempengaruhi pendanaan anggaran tahun berjalan setelah apropriasi awal.
Broom (1995) menyimpulkan bahwa pemberian informasi kinerja dalam proses penganggaran, walaupun tidak mentransformasi proses keputusan, namun memberikan nilai tambah pada pertimbangan. Konsisten dengan hal tersebut, Wang (2000) menemukan bahwa pengunaan pengukuran kinerja dalam penganggaran dipandang memiliki dampak positif pada kinerja organisasi. Penggunaan pengukuran kinerja dalam penganggaran disimpulkan dapat berdampak pada pemerintah, menentukan tujuan organisasi, memonitor praktik manajemen, dan dalam beberapa kasus membuat alokasi anggaran. Sedangkan penelitian Cavaluazzo and Ittner (2004) menunjukkan pengukuran kinerja merupakan kepatuhan terhadap akuntabilitas laporan publik.

Terkait implementasi anggaran berbasis kinerja terhadap terciptanya pengambilan keputusan pada dasarnya mendukung untuk terciptanya pengambilan keputusan yang lebih rasional (secara rasional). Penelitian Goodman and Clynch (2004) atas pengambilan keputusan anggaran oleh analis anggaran baik dari eksekutif maupun legislatif mendukung bukti dari penelitian-penelitian sebelumnya yang membenarkan kompleksitas faktorfaktor yang mempengaruhi keputusan analis anggaran.

Sedangkan terkait dengan aspek rasional, penelitian yang dilakukan oleh Julnez and Holzer (2001) tentang utilisasi kinerja pada organisasi publik yang melibatkan tahap adopsi dan implementasi, penelitian tersebut menyimpulkan bahwa kebijakan adopsi dalam utilisasi ukuran kinerja dipengaruhi oleh aspek rasional yang meliputi faktor sumber daya, informasi, orientasi tujuan organisasi publik.

Di Indonesia, Asmadewa (2006) melakukan penelitian tentang faktor-faktor yang mempengaruhi efektivitas implementasi anggaran berbasis kinerja menunjukkan bahwa yang meneliti faktor sumber daya dan 
informasi terhadap implementasi anggaran berbasis kinerja pemerintah pusat. Hasil dari penelitian ini menunjukkan adanya pengaruh yang signifikan pada faktor sumber daya dan informasi terhadap implementasi anggaran berbasis kinerja di pemerintah pusat.

\section{Pengembangan Hipotesis}

Berdasarkan literatur dan penelitian sebelumnya, pada bagian ini peneliti akan menghubungkan aspek rasional terhadap efektivitas implementasi anggaran berbasis kinerja. Aspek-aspek rasional yang diduga mempengaruhi proses implementasi meliputi sumber daya, informasi, orientasi tujuan, dan pengukuran kinerja. Oleh karena itu penelitian ini akan mengajukan proposisi bahwa aspek rasional mempengaruhi

Variabel Independen

Aspek Rasional dalam Penganggaran efektivitas implementasi anggaran berbasis kinerja.

$\mathrm{H} 1$ = Sumber daya berpengaruh positif terhadap efektivitas implementasi anggaran berbasis kinerja

$\mathrm{H} 2$ = Informasi berpengaruh positif terhadap efektivitas implementasi anggaran berbasis kinerja

H3 = Orientasi tujuan berpengaruh positif terhadap efektivitas implementasi anggaran berbasis kinerja

H4 = Pengukuran kinerja berpengaruh positif terhadap efektivitas pengimplemtasian anggaran berbasis kinerja.

Berdasarkan penjelasan di atas, kerangka pemikiran penelitian ini dapat digambarkan berikut ini.

\begin{tabular}{|c|c|c|}
\hline \multirow{2}{*}{ Sumber Daya } & $\mathrm{H} 1(+)$ & \multirow{5}{*}{$\begin{array}{c}\text { Efektivitas } \\
\text { Implementasi } \\
\text { Anggaran } \\
\text { Berbasis } \\
\text { Kinerja }\end{array}$} \\
\hline & $\mathrm{H} 2(+)$ & \\
\hline Informasi & $\mathrm{H} 3(+)$ & \\
\hline Orientasi Tujuan & $H 4$ & \\
\hline Pengukuran & $114(+)$ & \\
\hline
\end{tabular}

Gambar 1: Kerangka pemikiran penelitian 


\section{METODE PENELITIAN Pengumpulan Data dan Pemilihan Sampel}

Data dalam penelitian ini adalah data primer yang diperoleh melalui metode survei dengan menggunakan kuesioner. Populasi dalam penelitian ini adalah Satuan Kerja Perangkat Daerah pemerintah kota Surakarta, dimana Satuan Kerja Perangkat Daerah merupakan perangkat daerah pada pemerintah daerah selaku pengguna anggaran. Sedangkan sampel yang digunakan adalah pejabat pengguna anggaran dimana pejabat pengguna anggaran merupakan pejabat yang mempunyai kewenangan penggunaan anggaran untuk melaksanakan tugas pokok dan fungsi Satuan Kerja Perangkat Daerah yang dipimpinya.

Untuk pengambilan sampel ini, peneliti menggunakan metode purposive atau lebih tepatnya dengan judgement sampling untuk memilih anggota sampelnya (responden). Beberapa kriteria yang melandasi pemilihan responden adalah bahwa responden tersebut terlibat dalam perencanaan penyusunan anggaran, pengukuran kinerja dan dalam pengambilan keputusan anggaran serta yang nantinya mengembalikan kuesioner. Dalam Permendagri 13 tahun 2006 pasal 10 adalah pejabat pengguna anggaran adalah kepala Satuan Kerja Perangkat Daerah atau pejabat yang diberikan kewenangan atas penggunaan anggaran. Dimana Sesuai dengan Peraturan daerah no 6 tahun 2008 tentang organisasi dan tata kerja perangkat daerah kota Surakarta, satuan kerja perangkat daerah berjumlah 84 satuan kerja perangkat daerah sehingga nantinya kuesioner yang akan disebarkan sebanyak 84 yang ditujukan kepada pejabat pengguna anggaran pada tiap Satuan Kerja Perangkat Daerah.

\section{Pengukuran Variabel dan Definisi Operasional}

Penelitian ini menggunakan 5 variabel yang terdiri dari 1 variabel dependen (efektivitas implementasi anggaran berbasis kinerja) dan 4 variabel independen (sumber daya, informasi, orientasi tujuan dan pengukuran kinerja). Untuk kuesionernya sendiri diadopsi dari penelitian penelitian Willlougby and Melkers (2001), penelitian Julnes and Holzer (2001) dan penelitian Cavaluazzo and Ittner (2003)

Semua variabel dalam penelitian ini diukur dengan menggunakan skala likert dengan 4 skala poin, yakni 1 untuk skala terendah dan 4 untuk skala tertinggi sebagai pilihan tanggapan responden. Hal ini sesuai dengan penelitian yang terdahulu dan jawaban ragu-ragu (netral) dihilangkan dengan alasan kebanyakan subyek penelitian cenderung akan memilih jawaban yang netral (Hadi, 1994).

\section{Efektivitas implementasi anggaran berbasis kinerja}

Efektivitas implementasi anggaran berbasis kinerja adalah tahap penggunaan kinerja dalam proses penganggaran untuk memberikan dampak pada tingkat hasil program yang ditetapkan (Asmadewa, 2006). Sistem anggaran berbasis kinerja pada dasarnya merupakan sistem yang mencakup kegiatan penyusunan program dan tolak ukur kinerja sebagai instrumen untuk mencapai tujuan dan sasaran program (Mardiasmo, 2002).

\section{Sumber daya}

Sumber daya adalah komponen yang harus dimiliki perusahaan untuk mencapai tujuannya (Aliminsyah dan Padji, 2003). Sumber daya adalah faktor rasional yang mengukur sejauh mana organisasi memiliki sumber daya yang relevan untuk efektivitas implementasi anggaran berbasis kinerja (Asmadewa, 2006). Apabila terdapat sumber daya, yaitu staf dan dana dikhususkan untuk mengembangkan, mengumpulkan dan mengevaluasi kinerja maka akan berdampak pada pengadopsian suatu ukuran kinerja 
(Julnes and Holzer, 2001). Staf yang capable dan tersedianya sumber daya keuangan sangat penting dalam mengembangkan dan memantau ukuran kinerja (Wang, 2002).

\section{Informasi}

Informasi adalah data yang telah disaring, dianalisis, ditata, dan disampaikan dalam bentuk yang berguna untuk mencapai tujuan-tujuan organisasi (Anthony et. al. 1989). Informasi juga merupakan faktor rasional yang mencerminkan pengetahuan teknis (Asmadewa, 2006). Dalam implementasi pengukuran kinerja pegawai (manajemen) maupun pegawai (non manajemen) harus memiliki kemampuan teknis tentang bagaimana melakukan dan mengimplemtasikan pengukuran kinerja (Halim dan Sihaloho, 2005). Sehingga variabel ini menecrminkan data yang berguna yang dimiliki pegawai (manajemen) maupun pegawai (non manajemen) terkait akses terhadap peraturan, perundangan, literature yang terkait dengan pengukuran kinerja (Julnes and Holzer, 2001).

\section{Orientasi Tujuan}

Orientasi tujuan adalah faktor rasional yang mengukur sejauh mana organisasi berorientasi kepada pencapaian tujuan (Asmadewa, 2006). Hal ini seperti apa yang diungkapkan Halim dan Sihaloho (2006), bahwa orientasi tujuan merupakan konsesus terhadap tujuan dari setiap program. Selain itu orientasi tujuan juga dikonseptulisasikan sebagai suatu mental framework bagaimana individu menginterpretasi dan merespon situasi/kejadian yang dihadapinya (Ames and Archer, 1988).

\section{Pengukuran kinerja \\ Pengukuran kinerja merupakan} proses mencatat dan pencapaian pelaksanaan kegiatan dalam arah pencapaian misi melalui hasil-hasil yang ditampilkan berupa produk, jasa, ataupun suatu proses (Stout, 1993; dalam Bastian, 2006). Setiap kegiatan organisasi harus diukur dan dinyatakan keterkaitannya dengan visi dan misi. Produk dan jasa akan kehilangan nilai apabila kontribusi produk dan jasa tersebut tidak dikaitkan dengan pencapaian visi dan misi organisasi (Bastian, 2006).

\section{Pengujian Instrumen}

Dalam pengujian instrumen penelitian, uji validitas dan uji reliabilitas merupakan poin penting dalam sebuah analisa data. Hal itu dilakukan untuk menguji apakah suatu alat ukur atau instrumen penelitian sudah valid dan reliable (Wahyono, 2004).

\section{Uji Asumsi klasik}

Uji asumsi klasik merupakan uji yang digunakan sebagai syarat penggunaan metode regresi (Ghozali, 2001). Asumsi tersebut adalah asumsi normalitas, auto korelasi, multikolinearitas, dan heterokedastisitas.

\section{Pengujian Hipotesis}

Dalam penelitian ini hipotesis disusun untuk menemukan apakah terdapat pengaruh antara aspek rasional terhadap efektivitas implementasi anggaran berbasis kinerja. Oleh karena itu pengujian hipotesa dalam penelitian ini menggunakan analisis regresi berganda. Persamaan regresi untuk menguji hipotesis-hipotesis yang diajukan, dinyatakan dalam model berikut:

$$
Y=\alpha+\beta_{1} \cdot X 1+\beta_{2} \cdot X_{2}+\beta_{3} \cdot X_{3}+\beta_{4} \cdot X_{4}+\varepsilon
$$

Keterangan:

$\mathrm{Y}=$ Efektivitas implementasi anggaran berbasis kinerja

$\mathrm{X}_{1}=$ Sumber daya

$\mathrm{X}_{2}=$ Informasi

$\mathrm{X}_{3}=$ Orientasi tujuan

$\mathrm{X}_{4}=$ Pengukuran Kinerja

$\alpha=$ Konstansta 
$\beta=$ Koefisien

$\varepsilon=$ error term

\section{HASIL ANALISIS DAN PEMBAHASAN Statistik Deskriptif}

Jumlah responden yang berhasil terkumpul hingga batas akhir pengujian kuesioner adalah 75 sampel yang berasal dari 84 kuesioner yang disebar pada Satuan Kerja Perangkat Daerah. Tingkat pengembalian kuesioner adalah 89\% (75 dari 84 yang ditargetkan). Tetapi setelah di cek kembali ada 3 data sampel yang datanya tidak bisa diolah karena tanggapan atas kuisoner tidak lengkap sehingga hanya 72 data sampel yang bisa diolah (Tabel 1).
Adapun statistik deskriptif ditunjukkan oleh Tabel 2.

Selanjutnya secara detail disajikan nilai mean, median serta deviasi standar dari masing-masing variabel. Untuk kisaran teoritis ditentukan dari kemungkinan responden memilih semua jawaban dengan nilai atau poin terkecil dari masing-masing item dan kemungkinan responden memilih semua jawaban dengan nilai atau poin terbesar dari masing-masing item pertanyaan. Tetapi pada kenyataannya berdasarkan kisaran aktual dari jawaban responden ternyata cukup bervariasi dari jawaban yang mereka pilih.

Tabel 1: Karakteristik Sampel

\begin{tabular}{lcc}
\hline \multicolumn{1}{c}{ Karakteristik } & Mean & Kisaran \\
\hline Usia (tahun) & 44 tahun & $30-54$ tahun \\
Masa Kerja (tahun) & 19 tahun & $3-30$ tahun \\
Persentase dari sampel & Jumlah & $\%$ \\
Kelamin & & \\
$\bullet \quad$ Laki-laki & 49 orang & $68 \%$ \\
$\bullet \quad$ Perempuan & 23 orang & $32 \%$ \\
Pendidikan & & $4 \%$ \\
$\bullet \quad$ D3 & 3 orang & $65 \%$ \\
• S1 & 47 orang & $31 \%$ \\
\hline
\end{tabular}

Tabel 2: Statistik Deskristif

\begin{tabular}{lccccccc}
\hline \multicolumn{1}{c}{ Variabel } & & $\begin{array}{c}\text { Jumlah } \\
\text { item }\end{array}$ & Mean & Median & $\begin{array}{c}\text { Kisaran } \\
\text { Teoritis }\end{array}$ & $\begin{array}{c}\text { Kisaran } \\
\text { Aktual }\end{array}$ & $\begin{array}{c}\text { Deviasi } \\
\text { Standar }\end{array}$ \\
\hline Efektivitas Anggaran Berbasis Kinerja & $\mathrm{Y}$ & 7 & 21,0139 & 21 & $7-28$ & $13-26$ & 2,3406 \\
Sumber Daya & $\mathrm{X}_{1}$ & 5 & 15,2500 & 15 & $5-20$ & $9-20$ & 2,3721 \\
Informasi & $\mathrm{X}_{2}$ & 3 & 7,7917 & 8 & $3-12$ & $5-11$ & 1,4817 \\
Orientasi Kinerja & $\mathrm{X}_{3}$ & 4 & 11,9881 & 12 & $4-16$ & $8-15$ & 1,7562 \\
Pengukuran kinerja & $\mathrm{X}_{4}$ & 5 & 15,0139 & 15 & $5-20$ & $5-20$ & 2,6457 \\
\hline
\end{tabular}


Hasil Uji Validitas dan Realibilitas

Tabel 3: Hasil uji validitas dan reliabilitas

\begin{tabular}{lccc}
\hline \multicolumn{1}{c}{ Variabel } & & Kisaran Korelasi & Cronbach's Alpha \\
\hline Efektivitas Anggaran berbasis kinerja & $\mathrm{Y}$ & $0,579-0,693$ & 0,729 \\
Sumber Daya & $\mathrm{X}_{1}$ & $0,608-0,742$ & 0,695 \\
Informasi & $\mathrm{X}_{2}$ & $0,721-0,838$ & 0,697 \\
Orientasi Kinerja & $\mathrm{X}_{3}$ & $0,616-0,816$ & 0,623 \\
Pengukuran kinerja & $\mathrm{X}_{4}$ & $0,526-0,779$ & 0,754 \\
\hline
\end{tabular}

Hasil uji validitas dan realibilitas instrumen penelitian untuk pilot test yang dilakukan pada 31 mahasiswa magister akuntansi UNS menunjukkan bahwa item pertanyaan yang digunakan adalah valid dan reliabel. Hasil dari uji validitas berdasar data yang terkumpul menunjukkan bahwa semua item pertanyaan berkorelasi dengan skor total konstruk secara signifikan, dimana kisaran korelasinya adalah 0,431 sampai 0,845 . Sedangkan hasil uji reliabilitas nilai cronbach alphanya semua variabel juga lebih besar dari 0,6 yaitu berkisar antara 0,614 sampai 0,810 .

\section{Hasil Uji Asumsi Klasik}

Dari hasil uji normalitas menunjukkan bahwa besarnya nilainya KolmogorovSmirnov adalah 0,639 dan signifikansinya adalah 0,809 . Sehingga karena nilai signifikansinya lebih dari 0,05 maka dapat dikatakan bahwa data tersebut berdistribusi normal.

Sedangkan terkait uji multikolinearitas yang dilihat dari nilai tolerance value dan variance inflation factor (VIF), hasil analisis menunjukkan bahwa nilai VIF semua variabel independen di bawah nilai 10 dan Tolerance value diatas 0,10 . Sehingga dapat disimpulkan dari hasil diatas maka tidak ada multikolinearitas antar variabel independen dalam model regresi.

Untuk uji heteroskedastisitas, dalam penelitian ini dilakukan uji Glejser. Dimana dalam uji ini meregresi nilai absolut residual terhadap varibel independen. Dari hasil olah data yang dilakukan menunjukkan bahwa tidak ada satupun variabel yang secara signifikan secara statistik mempengaruhi variabel dependen nilai absolut.

Hal tersebut terlihat dari probabilitas signifikansinya di atas tingkat kepercayaan 5\%. Jadi dapat disimpulkan model regresi tidak mengandung adanya Heteroskedastisitas.

\section{Pengujian Hipotesis}

Hasil analisis statistik regresi berganda dapat dilihat pada Tabel 4. Dari hasil olah data dapat diketahui bahwa aspek rasional mempengaruhi efektivitas implementasi anggaran berbasis kinerja sebesar $29,4 \%$, sedangkan sisanya dipengaruhi aspek yang lain. Dari hasil olah data tersebut diketahui bahwa sumber daya dan pengukuran kinerja berpengaruh signifikan secara positif terhadap efektivitas pengimplementasian anggaran berbasis kinerja pada tingkat signifikansi 5\% (**) dan $1 \%$ (*). Untuk orientasi kinerja dari hasil diatas juga menunjukkan pengaruh yang signifikan secara negatif terhadap efektivitas pengimplementasian anggaran berbasis kinerja pada tingkat signifikansi $10 \% \quad(* * *)$. Sedangkan untuk informasi secara statistik tidak berpengaruh terhadap efektivitas pengimplementasian anggaran berbasis kinerja. 
Jurnal Siasat Bisnis Vol. 12 No. 2, Agustus 2008 Hal: 115-128

Tabel 4: Hasil analisis regresi implementasi anggaran berbasis kinerja pada faktor rasional

\begin{tabular}{|c|c|c|c|c|c|}
\hline \multirow{2}{*}{ Model } & \multicolumn{2}{|c|}{$\begin{array}{c}\text { Unstandardized } \\
\text { Coefficients }\end{array}$} & \multirow{2}{*}{$\begin{array}{c}\text { Standardized } \\
\text { Coefficients } \\
\text { Beta } \\
\end{array}$} & \multirow[t]{2}{*}{$\mathrm{t}$} & \multirow[t]{2}{*}{ Sig. } \\
\hline & B & Std. Error & & & \\
\hline (Constant) & 13,651 & 1,882 & & 7,254 & 0,000 \\
\hline SD & 0,274 & 0,124 & 0,277 & 2,207 & $0,031 * *$ \\
\hline INFO & 0,262 & 0,191 & 0,166 & 1,371 & 0,175 \\
\hline OT & $-0,318$ & 0,160 & $-0,239$ & $-1,982$ & $0,052 * * *$ \\
\hline PK & 0,331 & 0,114 & 0,374 & 2,906 & $0,005^{*}$ \\
\hline R-squared & 0,334 & & & & \\
\hline Adjusted $\mathrm{R}^{2}$ & 0,294 & & & & \\
\hline $\mathrm{F}$ & 8,347 & & & & \\
\hline
\end{tabular}

Berdasarkan hasil pengolahan data pada tabel 4 maka dapat dibentuk persamaan regresi sebagai berikut:

$Y=13,651+0,274 X_{1}+0,262 X_{2}-0,318 X_{3}$ $+0,331 \mathrm{X}_{4}$

\section{Pembahasan}

Hasil analisis regresi menunjukkan bahwa aspek sumber daya berpengaruh secara positif terhadap efektivitas implementasi anggaran berbasis kinerja pada pemerintah kota Surakarta. Temuan ini konsisten dengan penelitian Julnez dan Holzer (2001), yaitu sumber daya terbukti mempengaruhi tahap implementasi dalam pemanfaaatan indikator kinerja serta penelitian Asmadewa (2007) dimana menunjukkan adanya pengaruh yang signifikan pada faktor sumber daya terhadap implementasi anggaran berbasis kinerja di pemerintah pusat.

Dukungan sumber daya dalam setiap regulasi pada organisasi pemerintah pada umumnya merupakan hal yang formal yang harus dilakukan. Alokasi dana dan penetapan pegawai untuk melaksakan peraturan baru, serta waktu yang disediakan untuk hal tersebut lebih merupakan hal yang harus dilakukan sebagai bentuk respon birokrasi dan bentuk disiplin untuk menunjukkan bahwa organisasi telah melaksanakan hal yang tepat.
Sedangkan hipotesa kedua dan ketiga yang peneliti ajukan dalam penelitian ini tidak dapat diterima (ditolak). Hal ini dikarenakan dari hasil analisis data menunjukkan bahwa variabel informasi yang tidak berpengaruh secara signifikan terhadap efektivitas implementasi anggaran berbasis kinerja dan variabel orientasi tujuan mempunyai pengaruh negatif terhadap efektivitas implementasi anggaran berbasis kinerja

Pengaruh informasi yang tidak signifikan mempengaruhi efektivitas implementasi anggaran berbasis kinerja, diperkuat dengan para persepsi responden dimana belum menunjukkan sepenuhnya hal yang kondusif. Hal ini dikarenakan sebagian besar responden (hampir mencapai 50\%) mengindikasikan tidak pernah atau jarang mengikuti pelatihan atau workshop atau seminar tentang anggaran berbasis kinerja khususnya bagi pegawai non manajemen atau pegawai yang tidak mempunyai jabatan dalam instansinya.

Pengaruh negatif variabel orientasi tujuan terhadap efektivitas implementasi anggaran berbasis kinerja pada pemerintah kota Surakarta menurut peneliti karena para penganggar tidak memiliki orientasi tujuan terkait dengan anggaran berbasis kinerja. Orientasi menghabiskan anggaran tanpa memperhatikan kualitas output dan tujuan 
program yang telah disusun dalam perencanaan strategis pelaksanaan anggaran merupakan paradigm anggaran tradisional. Dimana paradigma tersebut bertolak belakang dengan anggaran berbasis kinerja yang memperhatikan keterkaitan dana publik dengan output dan tujuan program. Hal ini terjadi karena kompetensi pejabat pengguna anggaran dalam hal pemahaman anggaran berbasis kinerja masih belum optimal.

Terkait dengan variabel pengukuran kinerja, variabel ini secara signifikan berpengaruh secara positif terhadap efektivitas anggaran berbasis kinerja pada pemerintah kota Surakarta. Hal ini mengindikasikan bahwa hipotesis keempat yang peneliti aujkan diterima. Temuan ini konsisten dengan hasil penelitian Cavaluazzo dan Ittner (2003) yang memberikan bukti yang kuat dalam pengembangan ukuran kinerja berpengaruh secara positif terhadap aktifitas atau program berorientasi pada hasil.

Keberhasilan efektivitas implementasi anggaran berbasis kinerja sangat ditentukan dengan pengukuran kinerja yang ada, karena pengukuran kinerja yang digunakan dalam penyususnan anggaran sangat mengandalkan keakuratan informasi dari sistem tersebut dan pengukuran kinerja merupakan suatu bentuk kepatuhan terhadap akuntabilitas laporan publik. Dari hasil analisis juga menunjukkan bahwa pengukuran kinerja yang tepat dan akurat menjadi dasar penyusunan anggaran telah berusaha dilakukan sebagai upaya efektivitas implementasi anggaran berbasis kinerja.

Berdasar analisa data mengindikasikan bahwa perkembangan efektivitas implementasi anggaran berbasis kinerja pada pemerintah kota Surakarta saat ini belum sepenuhnya menyentuh seluruh aspek rasional.

Terkait aspek-aspek rasional yang belum cukup menjelaskan kemajuan implementasi anggaran berbasis kinerja peneliti berpendapat bahwa hal ini mungkin disebabkan oleh sampel yang didapatkan belum sepenuhnya mewakili kondisi saat ini dan perkembangan pengimplementasian baru memasuki tahap awal. Untuk mencapai tingkat yang efektif masih diperlukan waktu yang panjang dan perlu perbaikan pada aspek rasional sehingga nantinya mampu mempengaruhi efektivitas anggaran berbasis kinerja.

\section{PENUTUP}

Hasil analisis regresi menunjukkan bahwa aspek sumber daya berpengaruh secara positif terhadap efektivitas implementasi anggaran berbasis kinerja pada pemerintah kota Surakarta. Hal ini berarti hipotesis pertama yang peneliti ajukan diterima. Temuan ini konsisten dengan penelitian Julnez dan Holzer (2001), yaitu sumber daya terbukti mempengaruhi tahap implementasi dalam pemanfaaatan indikator kinerja serta penelitian Asmadewa (2007) dimana menunjukkan adanya pengaruh yang signifikan pada faktor sumber daya terhadap implementasi anggaran berbasis kinerja di pemerintah pusat.

Sedangkan hipotesa kedua dan ketiga yang peneliti ajukan dalam penelitian ini tidak dapat diterima (ditolak). Hal ini dikarenakan dari hasil analisis data menunjukkan bahwa variabel informasi yang tidak berpengaruh secara signifikan terhadap efektivitas implementasi anggaran berbasis kinerja dan variabel orientasi tujuan mempunyai pengaruh negatif terhadap efektivitas implementasi anggaran berbasis kinerja.

Terkait dengan variabel pengukuran kinerja, variabel ini secara signifikan berpengaruh secara positif terhadap efektivitas anggaran berbasis kinerja pada pemerintah kota Surakarta. Hal ini mengindikasikan bahwa hipotesis keempat yang peneliti aujkan diterima. Temuan ini konsisten dengan hasil penelitian Cavaluazzo dan 
Ittner (2003) yang memberikan bukti yang kuat dalam pengembangan ukuran kinerja berpengaruh secara positif terhadap aktifitas atau program berorientasi pada hasil.

Peneliti menyimpulkan untuk mencapai tingkat yang efektif masih diperlukan waktu yang masih panjang dan perlu perbaikan pada aspek rasional sehingga nantinya mampu mempengaruhi pengambilan keputusan anggaran yang pada gilirannya dapat mempengaruhi efektivitas anggaran berbasis kinerja.

Adapun keterbatasan dalam penelitian ini meliputi:

1. Penelitian ini memiliki keterbatasan yang dialami penelitian persepsian pada umumnya, yaitu masalah subyekstivitas responden. Keterbatasan ini membuat penelitian rentan terhadap biasnya jawaban responden. Untuk itu temuan dalam penelitian ini harus dimaknai dengan hati-hati

2. Berdasarkan pengalaman penulis dalam survey ini, banyak sekali informasiinformasi yang terkait dengan pengimplementasian anggaran berbasis kinerja Pemerintah Kota Surakarta yang tidak ditangkap dalam kuesioner penelitian.

3. Mengingat objek penelitian ini hanya dilakukan pada lingkup Pemerintah Kota Surakarta dan belum mencakup kabupaten lain khususnya untuk Propinsi Jawa Tengah, jadi penelitian ini belum dapat digeneralisir secara luas.

Akhirnya, saran untuk penelitian berikutnya adalah:

1. Penelitian ini hanya mencakup persepsi pejabat pengguna anggaran atau pejabat yang diberikan kekuasaan oleh pejabat pengguna anggaran yang memahami anggaran berbasis kinerja. Untuk penelitian selanjutnya, penelitian dapat diperluas dengan melibatkan Biro Perencanaan, Biro Keuangan, Biro pro- gram termasuk program dan unit organisasi yang meliputinya. Sehingga data yang didapatkan dari satuan-satuan kerja tersebut dapat menggambarkan dinamika yang sebenarnya terjadi.

2. Penelitian selanjutnya juga dapat memasukkan aspek budaya atau politis seperti dukungan inernal, dukungan eksternal, sikap keterbukaan organisasi pada perubahan (Julnez dan Holzer, 2001) untuk melihat perbedaan pengaruh aspek rasional dan aspek politis serta budaya dalam pengimplemetasian anggaran berbasis kinerja.

3. Dalam penelitian yang lain dapat dilakukan dengan data sekunder untuk membuktikan keefektifan implementasi anggaran berbasis dan melengkapi hasil temuan penelitian persepsian ini.

\section{DAFTAR PUSTAKA}

Anthony, R. N., Dearden, J. dan Bredford, N.M. (1992). Sistem Pengendalian Manajemen. Jakarta. Binarupa Aksara.

Ames, C. dan Archer, J. (1988). Achievement Goals in the Classroom: Students' Learning Strategies and Motivation Processes. Journal of Educational Psychology, 80, 260267.

Asmadewa, I. (2006). Faktor-Faktor Yang Mempengaruhi Keefektifan Implementasi Anggaran Berbasis Kinerja (Survei pada Pemerintah Pusat). Thesis UGM. Unpublished.

Bastian, I. (2006). Akuntansi Sektor Publik: Suatu Pengantar. Jakarta. Penerbit Erlangga.

Broom, C. A. (1995). Performance-Based Government Models: Building a Tracks Record. Public Budgeting and Finance, 15 (4), 3-17. 
Cavaluazzo, K. S. and Ittner, C. D. (2003). Implementing performance measurenent innovations: evidence from government. Accounting Organization and Society, April/may, 29, 243-268.

Crain, W. M. dan O’Roack, J.B. (2004). The impact of performance-based budgeting on state fiscal performance. Economics of governance, 15, 168186.

Darmansjah, I. (2002). Strategic Plannings. Available at: http://www. iwandarmansjah.web.id

Departemen Dalam Negeri. (2006). Peraturan Menteri Dalam Negeri No. 13 tahun 2006 tentang Pedoman Pengelolaan Keuangan Daerah. www.depdagri.go.id.

Departemen Dalam Negeri. (2006). Peraturan Menteri Dalam Negeri No. 59 tahun 2007 tentang Pedoman Pengelolaan Keuangan Daerah. www.depdagri.go.id.

General Accounting Office. (1993). Performance Budgeting, State Experience and Implications for the Federal Government. GAO/AFMD93-41. Washington D.C.

. (2005). Performance Budgeting: Efforts to Restructures Budget to Better Align Resources with Performance. GAO-05-117. Washington D.C.

Ghozali, I. (2001). Aplikasi Analisis Multivariate dengan program SPSS. Semarang: Penerbit UNDIP.

Goodman, D. dan Clynch, E.J. (2004). Budgetery decision making by eksekutif and legislative budget analysts: The impact of politicial Cues and Analytical Information.
Public Budgetering \& Finance, Fall, 20-37.

Hadi, S. (1994). Metode Reseach I. Yogyakarta: Andy Offset.

Halim, A. dan Sihaloho, F.L. (2005). Pengaruh faktor-faktor rasional, politik dan kultur organisasi terhadap pemanfaatan informasi kinerja instansi pemerintah daerah. SNA VII, 774-790.

Hood, C. (1991). A Public Management for All Seasons?, Public Administration, 61 (Spring), 143-149.

Howard, S. K. (1973). Changing State Budgeting. Lexington KY: Council of State Goverments.

Jordan, M. M. dan Harkbart, M. (2005). The Goal and Implementing Succes of state Performance-based Budgeting, Journal of Public Budgeting, Accounitng and Financial Management, 17 (4), 471-489.

Joyce, P. G. (1993). Using Performance measures for federal budgeting: Proposals and prospects. Public budgeting finance, 13 (4), 3-17.

Julnes, P. deL. and Holzer, M. (2001). Promoting the Utilization of Performance Measures in Public Organizations, An Empirical Study of Faktor Affecting Adaptation and Implementation, Public Administration Review, 61 (6), 693701.

Mardiasmo. (2002). Akuntansi Sektor Publik. Andi Yogyakarta.

Osborne, D. dan Gaebler, T. (1993). Reinventing Government, How the Entrepreneurial Spirit is Transforming the Public Sector. Reading Mass: Addison-Wesley. 
Peraturan Daerah Kota Surakarta. (2008). Organisasi dan Tata Kerja Perangkat Daerah Kota Surakarta. www.hukumdanham.surakarta.go.id

Robinson, M. dan Brumby, J. (2005). Does Performance Budgeting Work? An Analytical Review of the empirical literature. IMF Working Paper $\mathrm{WP} / 05 / 210$.

Wahyono, T. (2004). Cara Mudah Melakukan Analisa Statistik Dengan SPSS. Gava Media.

Wang, X. (2000). Performance Measurement in Budgeting: A Study in
Country government. Public Budgeting and Finance, 20 (3), 105-120.

Willoughby, K. G. and Melkers, J.E. (2000). Implementing PBB (Performance Based Budgeting): Confilcting Views of Succes. Public Budgeting and Finance, 20. 105-120.

Willoughby, K. G. and Melkers, J.E. 2001. Budgeter's Views of State Performance Based Budgeting Systems. Public Administrations Review, 61 (1), 54-64. 